\title{
MODEL PENINGKATAN RETURN SAHAM DAN KINERJA KEUANGAN MELALUI CORPORATE SOCIAL RESPONSIBILITY DAN GOOD CORPORATE GOVERNANCE DI BURSA EFEK INDONESIA
}

\author{
Mutamimah (tatikmut@yahoo.com) \\ Sri Hartono (srihartrs@yahoo.co.id) \\ Eviatiwi Kusumaningtyas Sugiyanto (eviatiwi.sugiyanto@gmail.com) \\ Universitas Islam Sultan Agung
}

\begin{abstract}
The purpose of this research was to find an empiric proof and analysis that stock return and financial performance of the companies could be improved through Corporate Social Responsibility (CSR) and Good Corporate Governance (GCG) at The Indonesian Capital Market. Population of this research are companies that go public at Indonesia Capital Market. Technic Sampling used purposive sampling, and find 62 companies. This companies then were divided into two categories according to its total assets. From its, 31 samples categorized as big companies, while others as small companies. And the hypotheses were tested using Structural Equation Modeling (SEM) with Partial Least Square (PLS) program. The result showed that (1) CSR had a significant positive effect towards stock return in big companies categorized, while small companies categorized had a significant negative effect of it, (2) GCG had no significant effect towards stock return in both categories, (3) Financial performance had no significant effect towards stock return in big companies categorized, but it had a positive significant effect towards it in those small, (4) CSR had a significant positive effect towards financial performance in big companies categorized, whereas in small companies it could not be found, (5) GCG had no significant effect towards financial performance in both categories, (6) as well as the GCG had no significant effect towards CSR in both categories.
\end{abstract}

Keywords: Corporate Social Responsibility, Good Corporate Governance, Stock Return, and Financial Performance

\section{PENDAHULUAN}

Secara umum tujuan utama perusahaan adalah memaksimalkan kesejahteraan pemegang saham (maximization wealth of stockholder). Dengan prinsip ini beberapa perusahaan mengabaikan pihak-pihak lain yang berkepentingan terhadap perusahaan, sehingga memunculkan tekanan publik yang berdampak negatif bagi perusahaan. Dampak tersebut dapat mengganggu kinerja keuangan perusahaan dan mengakibatkan turunnya harga saham, karena hilangnya kepercayaan investor akibat citra buruk yang ditimbulkan perusahaan. Hal ini telah mengubah pola pikir para pelaku bisnis untuk memperhatikan pemangku kepentingan lain di luar para stockholder. Pemikiran ini sejalan dengan stakeholder theory yang menjelaskan bahwa perusahaan tidak hanya bertanggung jawab pada stockholder saja tetapi juga pada stakeholder (Freeman dalam Jalal 2009). Kegiatan Corporate Social Responsibility (CSR) dan Good Corporate Governance (GCG) merupakan kegiatan yang sejalan dengan konsep stakeholder theory.

CSR adalah Kepedulian perusahaan yang tidak hanya mencari laba (profit), tetapi juga membangun manusia (people) dan lingkungan (planet) secara berkelanjutan berdasarkan prosedur yang ditentukan (Suharto 2008). GCG merupakan sistem untuk mengarahkan dan mengendalikan perusahaan (Ismail Solihin 2008). Struktur GCG menetapkan distribusi hak dan kewajiban antara berbagai pihak yang terlibat dalam suatu korporasi. Orientasi keputusan CSR dan GCG selalu bermuara pada kepentingan stakeholder.

Perusahaan publik yang dituntut keterbukaan dalam berbagai informasi, CSR dan GCG seharusnya menjadi bagian tak terpisahkan dalam bisnis. Namun fenomena yang terjadi di 
Bursa Efek Indonesia, kegiatan CSR dan GCG umumnya masih dalam kategori yang implementasinya belum maksimal. Tahun 2005-2006 pengungkapan tema-tema CSR perusahaan publik tidak lebih dari 30\% (Monika 2008). Sedangkan menurut lembaga survei GCG di Indonesia yaitu Corporate Governance Perception Index (CGPI), jumlah peserta survei GCG dari tahun ke tahun tidak menunjukkan kenaikan yang signifikan. Peserta tahun 2001-2005 berkisar antara 22-52 perusahaan. Hal tersebut setidaknya merefleksikan keraguan perusahaan publik mengenai insentif langsung yang akan diterima apabila melaksanakan CSR dan GCG.

Pranata (2007) menemukan pengaruh positif signifikan antara GCG terhadap kinerja keuangan dan kinerja pasar perusahaan. Sementara itu, Wardani (2008) tidak menemukan pengaruh GCG terhadap kinerja keuangan maupun kinerja pasar. Penerapan GCG dalam perusahaan dapat mendorong pelaksanaan dan pengungkapan CSR (Ismail Solihin 2008). Hal ini mengindikasikan bahwa GCG mempunyai pengaruh terhadap CSR. Beberapa studi telah dilakukan untuk menganalisis pengaruh CSR terhadap return saham maupun kinerja keuangan. Dahli (2008) tidak menemukan pengaruh signifikan CSR terhadap return saham tetapi menemukan pengaruh positif signifikan CSR terhadap kinerja keuangan. Sayekti (2007) menemukan pengaruh positif signifikan CSR terhadap return saham. Sedangkan Monika (2008) dan Fauzi (2007) tidak menemukan pengaruh signifikan CSR terhadap kinerja keuangan. Kaitannya dengan pengaruh kinerja keuangan terhadap return saham, Taufik (2007) menemukan bahwa secara signifikan semakin tinggi nilai kinerja keuangan, maka semakin tinggi return saham yang dinikmati oleh para pemegang saham. Sedangkan Hakim (2006) tidak menemukan pengaruh signifikan kinerja keuangan terhadap return saham.

Hasil penelitian-penelitian terdahulu menandakan adanya research gap (tidak konsistennya temuan-temuan penelitian). Tidak konsistennya temuan penelitian disebabkan adanya variabel kondisional yang menginteraksi pengaruh antar variabel penelitian (Amalia 2007). Sebagai variabel kondisional peneliti menggunakan size perusahaan. Monika (2008) menemukan pengaruh positif signifikan size terhadap CSR. Wardani (2008) menemukan size berpengaruh positif signifikan terhadap GCG. Sehingga berdasarkan size, peneliti membagi perusahaan dalam dua kategori yaitu kategori besar dan kecil.

Fenomena tersebut mendorong peneliti untuk menguji dan menganalisis Bagaimana meningkatkan return saham dan kinerja keuangan perusahaan melalui Corporate Social Responsibility (CSR) dan Good Corporate Governance (GCG) dengan mengelompokkan perusahaan ke dalam kategori besar dan kecil.

\section{TINJAUAN PUSTAKA DAN PENGEMBANGAN HIPOTESIS}

\section{Size perusahaan berdampak pada pengaruh CSR terhadap return saham.}

Return saham dapat diartikan sebagai imbalan atas sejumlah dana yang telah diinvestasikan dalam saham. Laporan tahunan merupakan salah satu sumber informasi bagi para investor. Dengan demikian tingkat pengungkapan dalam laporan tahunan akan berdampak pada pergerakan harga saham yang pada gilirannya berdampak pada return (Junaedi dalam Dahli 2008). Dikatakan pengumuman atau pengungkapan mengandung informasi jika ada abnormal return. Abnormal return merupakan kelebihan return yang sesungguhnya terjadi terhadap return ekspektasi (Hartono 2008).

Dari perspektif ekonomi, perusahaan akan mengungkapkan suatu informasi jika informasi tersebut dapat meningkatkan nilai perusahaan. Salah satunya adalah program CSR. Sayekti, dkk (2007) menerangkan bahwa perusahaan yang melaksanakan kegiatan CSR cenderung mendapat legitimasi dari masyarakat, sehingga konflik kepentingan antara masyarakat dan perusahaan dapat diminimalkan. Hal tersebut akan menarik para investor untuk berinvestasi di perusahaan tersebut. Sayekti dkk (2007) menemukan pengaruh positif signifikan CSR terhadap return saham. Namun, Dahli (2008) tidak menemukan pengaruh CSR terhadap 
return saham. Perusahaan besar lebih banyak melaksanakan CSR daripada perusahaan kecil (Monika 2008). Hal ini terjadi karena perusahaan besar menarik perhatian yang lebih banyak dari para konstituen eksternal sehingga lebih dituntut untuk memberikan respon yang lebih tinggi terhadap stakeholder. Maka hipotesis yang dapat dirumuskan adalah

\section{H1 : Size perusahaan berdampak pada pengaruh CSR terhadap return saham.}

\section{Size perusahaan berdampak pada pengaruh GCG terhadap Return Saham.}

Studi Pranata (2007) menemukan bahwa semakin baik penerapan GCG, maka semakin tinggi return sahamnya. Namun Wardani (2008) tidak menemukan pengaruh signifikan GCG terhadap return saham. GCG diukur berdasarkan mekanisme internal perusahan yaitu kepemilikan manajerial, komisaris independen, komite audit (Isnanta 2008), dan kepemilikan institusional (Bodroastuti 2009). Kepemilikan manajemen dalam perusahaan dipandang dapat menyelaraskan potensi konflik kepentingan antara pemegang saham luar dengan manajemen (Jansen dan Meckling dalam Isnanta 2008). Beasly dalam Isnanta (2008) menyatakan bahwa komisaris independen meningkatkan efektivitas dalam mengawasi manajemen untuk mencegah kecurangan laporan keuangan. Penelitian mengenai komite audit yaitu oleh Davidson, Xie, dan XU dalam Isnanta (2008) yang menunjukkan bahwa pasar bereaksi positif terhadap pengumuman penunjukan anggota komite audit. Kepemilikan institusional yang tinggi akan menimbulkan usaha pengawasan yang lebih besar sehingga dapat menghalangi perilaku opportunistik manajer (Machmud 2008). Mekanisme internal tersebut dapat menguntungkan para investor, sehingga akan meningkatkan return. Kaitannya dengan size, perusahaan besar dapat memiliki masalah keagenan yang lebih besar (karena lebih sulit untuk dimonitor) sehingga membutuhkan corporate governance yang lebih baik (Wardani 2008). Jadi hipotesis yang dapat dirumuskan adalah

\section{H2 : Size perusahaan berdampak pada pengaruh GCG dengan return saham}

\section{Size perusahaan berdampak pada pengaruh kinerja keuangan dengan return saham}

Kinerja keuangan merupakan capaian suatu organisasi yang diukur berdasarkan aspek financial. Alat analisis yang sering digunakan untuk mengukur kinerja keuangan adalah rasio keuangan. Tetapi penggunaan rasio keuangan memiliki kelemahan utama yaitu mengabaikan adanya biaya modal, sehingga sulit untuk mengetahui apakah perusahaan telah menciptakan nilai atau tidak. Untuk itu dikembangkan konsep Economic Value Added (EVA). EVA mencerminkan residual income yang tersisa setelah semua biaya modal, termasuk modal saham, telah dikurangkan.

Berkaitan dengan EVA sebagai alat ukur kinerja yang mempertimbangkan harapan para investor terhadap investasi yang dilakukan, maka EVA mengidentifikasi seberapa jauh perusahaan telah menciptakan nilai bagi pemilik perusahaan (Hakim 2006). Namun Hakim (2006), Utami (2006) dan Rahayu (2007) tidak menemukan pengaruh EVA terhadap return saham. Sedangkan Taufik (2007) menemukan pengaruh positif signifikan EVA terhadap return saham. Kaitannya dengan size perusahaan, Wahyudi dalam Dahli (2008) menerangkan bahwa perusahaan besar dianggap lebih mampu untuk menghasilkan kinerja keuangan yang tinggi, karena mereka mampu mengontrol kondisi pasar dan kurang rentan terhadap fluktuasi ekonomi. Maka hipotesis yang dapat dirumuskan adalah 


\section{Size perusahaan berdampak pada pengaruh CSR terhadap Kinerja Keuangan}

CSR merupakan komitmen perusahaan dalam mengintegrasikan aspek sosial, dan lingkungan ke dalam operasi bisnis secara berkelanjutan guna menyeimbangkan kepentingan dan kesejahteraan stakeholder. Penelitian dalam lingkup CSR umumnya menggali bagaimana penerapan aktivitas tersebut dalam perusahaan, dengan melihat pengungkapannya di dalam laporan tahunan. Menurut Glouter dalam Nurlela (2008), tematema CSR meliputi (1) Kemasyarakatan, (2) Produk dan Konsumen, (3) Ketenagakerjaan, (4) Lingkungan Hidup.

Menurut Andreas Lako (2008) CSR bukan merupakan beban tetapi merupakan sebuah investasi. Bisnis yang ramah CSR, akan memunculkan rasa kecintaan para stakeholder sehingga korporasi bisa diterima, dicintai, dikasihi, dan dihidupi para stakeholder secara berkesinambungan. Dalam penelitian Dahli dkk (2008) dan Margarita Tsoutsoura (2004) ditemukan pengaruh positif signifikan CSR terhadap kinerja keuangan perusahaan. Sedangkan dalam penelitian Monika dkk (2008), Nurlela dkk (2008) dan Fauzi dkk (2007) tidak ditemukan pengaruh signifikan CSR terhadap kinerja keuangan. Menurut Itoken dalam Fauzi (2007) perusahaan besar lebih banyak melakukan kegiatan CSR dibanding perusahaan kecil. Perusahaan yang berada pada situasi survival, dimana keuntungan yang diperoleh relatif kecil, secara logis akan lebih memilih aktivitas marketing daripada CSR (Handoyo 2008). Maka hipotesis yang dapat dirumuskan adalah:

\section{H4 : Size perusahaan berdampak pada pengaruh CSR terhadap kinerja keuangan}

\section{Size Perusahaan berdampak pada Pengaruh GCG terhadap Kinerja Keuangan}

GCG adalah suatu tata kelola perusahaan untuk mengurangi konflik kepentingan antar para pemangku kepentingan, sehubungan dengan hak dan kewajibannya. Prinsip GCG meliputi transparasi, akuntabilitas, responsibilitas, independensi, kewajaran dan kesetaraan (Ismail Solihin 2008). Menurut Lins, dkk dalam Amalia (2007) secara umum mekanisme GCG dapat diklasifikasikan dalam dua kelompok yaitu mekanisme internal perusahaan (struktur kepemilikan dan struktur pengelolaan) dan mekanisme eksternal spesifik Negara (aturan hukum dan pasar pengendalian corporate).

Jansen dan Meckling dalam Isnanta (2008) menunjukkan bahwa untuk meminimalkan konflik keagenan adalah dengan meningkatkan kepemilikan manajerial di dalam perusahaan. Mekanisme intern perusahaan lainnya adalah dewan komisaris. Efektivitas dewan komisaris dalam menyeimbangkan kekuatan CEO sangat dipengaruhi oleh tingkat independensi di dewan komisaris. Komisaris independen merupakan anggota dewan komisaris yang tidak terafiliasi dengan perusahaan sehingga mampu bertindak independen (Komite Nasional Kebijakan Governance dalam Isnanta 2008). Komite audit sesuai dengan Kep. 29/PM/2004 adalah komite yang dibentuk oleh dewan komisaris untuk melakukan tugas pengawasan pengelolaan perusahaan. Komite audit dianggap sebagai penghubung antara pemegang saham dan dewan komisaris dengan pihak manajemen dalam menangani masalah pengendalian (Isnanta 2008). Semakin besar kepemilikan institusional maka semakin efisien pemanfaatan aktivanya (Bodroastuti 2009). Kepemilikan institusional yang besar (lebih dari 5\%) mengindikasikan kemampuan untuk memonitor manajemen.

Isnanta (2008) menemukan bahwa GCG yang diukur dengan kepemilikan manajerial, komisaris independen dan komite audit berpengaruh positif signifikan terhadap kinerja keuangan. Bodroastuti (2009) menemukan pengaruh negatif signifikan kepemilikan institusional terhadap financial distress. Dalam penelitian Pranata (2007) juga ditemukan pengaruh positif signifikan GCG terhadap kinerja keuangan. Namun dalam penelitian Wardani (2008) tidak ditemukan pengaruh signifikan GCG terhadap kinerja keuangan. Pengaruh ukuran perusahaan terhadap GCG masih belum jelas arahnya. Perusahaan besar dapat memiliki masalah keagenan yang lebih besar (karena lebih sulit untuk dimonitor) 
sehingga membutuhkan corporate governance yang lebih baik (Wardani 2008). Jadi dari uraian-uraian sebelumnya, hipotesis yang dapat dirumuskan adalah:

\section{H5 : Size perusahaan berdampak pada pengaruh GCG terhadap kinerja keuangan}

\section{Size perusahaan berdampak pada pengaruh GCG terhadap CSR}

CSR juga menjadi salah satu prinsip pelaksanaan GCG yaitu prinsip responsibilitas, dimana dalam prinsip tersebut dinyatakan "Perusahaan harus mematuhi peraturan perundangundangan serta melaksanakan tanggung jawab terhadap masyarakat dan lingkungan sehingga dapat terpelihara kesinambungan usaha dan mendapat pengakuan sebagai good corporate citizen" (Ismail Solihin 2008). Size perusahaan, Cooke dalam Arifin (2005) menjelaskan bahwa perusahaan besar lebih banyak melakukan pengungkapan dan transparan dalam setiap informasi daripada perusahaan kecil, termasuk melakukan pengungkapan tema-tema tanggung jawab sosial. Maka hipotesis yang dirumuskan:

\section{H6 : Size perusahaan berdampak pada pengaruh GCG terhadap CSR}

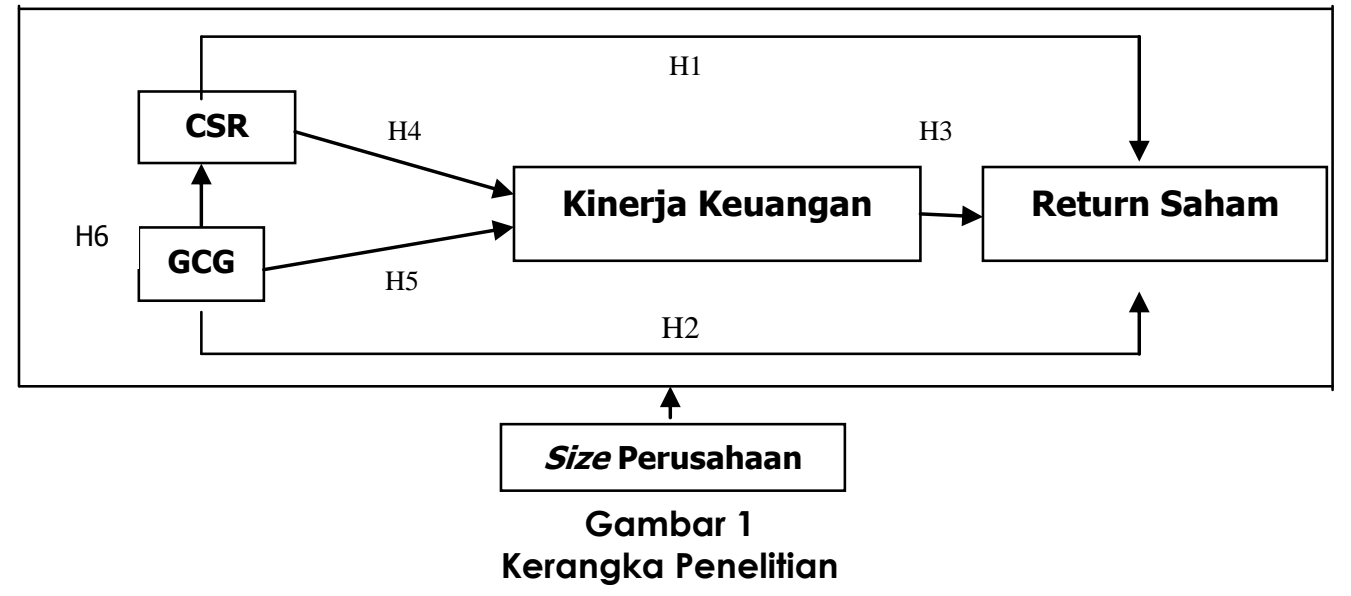

\section{METODE PENELITIAN}

\section{Populasi dan Sampel}

Populasi dalam penelitian ini adalah seluruh perusahaan yang terdaftar di BEl tahun 2007 dengan jumlah 392 perusahaan. Sampel berjumlah 62 perusahaan dipilih dengan metode purposive sampling, dengan kriteria sebagai berikut: (1) Terdaftar di BEl tahun 2007; (2) Mempublikasikan laporan keuangan tahun 2007; (3) Mempublikasikan laporan tahunan tahun 2007; (4) Tidak Melakukan Stock Split selama estimasi.

\section{Sumber dan Jenis Data}

Penelitian ini menggunakan sumber data sekunder yaitu dari ICMD tahun 2007 untuk return saham, kinerja kevangan, GCG dan size. Dan CSR diperoleh dari Laporan tahunan perusahaan atau sustainability report tahun 2007 melalui website perusahaan.

\section{Definisi Operasional Variabel}

\section{a. Variabel Return Saham}

Return saham adalah imbalan atas sejumlah dana yang diinvestasikan dalam saham. Return saham yang digunakan adalah Abnormal return (market adjusted model). Jangka waktu yang optimal dalam menghitung return adalah 15 bulan (Collins dalam Sayekti 2008). 


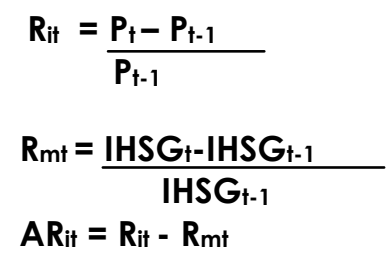

Keterangan

$\mathrm{AR}_{\text {it }} \quad$ : Abnormal return untuk perusahaan i pada periode $\dagger$

Rit \& $R_{m t} \quad$ : Return perusahaan i pada periode $t$ dan Return indeks pasar pada periode $\dagger$

$P_{\dagger} \& P_{t-1} \quad$ : Harga saham pada periode $t$ dan Harga saham pada periode $t_{-1}$

IHSG \& IHSGt-1 : Indeks harga saham gabungan pada waktu † dan pada waktu t-1

\section{b.Variabel Kinerja Keuangan}

Kinerja keuangan merupakan capaian suatu organisasi yang diukur berdasarkan aspek financial. Kinerja keuangan perusahaan diukur dengan menggunakan Economic Valve Added (EVA).

\section{EVA $=$ NOPAT - Biaya Modal Setelah Pajak}

Keterangan:

NOPAT : Net Operating Profit After Tax

Biaya Modal Setelah Pajak : :WACC x Invested Capital

\section{c.Variabel Corporate Social Responsibility}

CSR adalah komitmen perusahaan mengintegrasikan aspek sosial, dan aspek lingkungan ke dalam operasi bisnis secara berkelanjutan untuk meningkatkan kesejahteraan stakeholder. CSR diukur berdasarkan pengungkapan informasi CSR dalam laporan tahunan perusahaan sesuai dengan 4 item pengungkapan menurut Nurlela (2008).

$$
\text { CSRIj }=\frac{\Sigma X i j}{N j}
$$

Keterangan:

CSRIj : Corporate Social Responsibility Disclosure Index perusahaan j

nj : Jumlah item pengungkapan, $\mathrm{n}: 32$

Xij $\quad: 1$ = jika item i diungkapkan; 0 = jika item i tidak diungkapkan

\section{d.Variabel Good Corporate Governance}

GCG adalah suatu tata kelola perusahaan untuk mengurangi konflik kepentingan antar para pemangku kepentingan, sehubungan dengan hak dan kewajibannya. Kepemilikan manajerial diukur dengan persentase saham yang dimiliki pihak manajemen dari seluruh modal saham perusahaan yang beredar. Komisaris independen diukur dengan persentase anggota dewan komisaris yang berasal dari luar perusahaan dari seluruh anggota dewan komisaris perusahaan. Komite audit diukur dengan menggunakan persentase anggota komite audit yang berasal dari luar anggota komisaris independen terhadap seluruh anggota komite audit. Kepemilikan institusional diukur berdasarkan persentase saham yang dimiliki oleh investor institusional pada perusahaan dari seluruh modal saham perusahaan yang beredar. 


\section{e.Variabel Size}

Size digunakan sebagai variabel kontrol. Size diukur dengan total asset (Monika 2008). Nilai median dari seluruh asset perusahaan sampel digunakan sebagai standar penggolongan. Asset $\geq$ nilai median masuk dalam kategori size besar, dan sebaliknya.

\section{Teknik Analisis}

Teknik analisis yang digunakan adalah Structural Equation Modeling (SEM) dengan menggunakan program Partial Least Square (PLS). Analisis PLS meliputi Uji Outer Model dan Inner Model. Outer model digunakan untuk mengetahui validitas dan reliabilitas indikator, sedangkan Inner model digunakan untuk menguji signifikansi parameter yang dirumuskan dalam hipotesis (Ghozali dan Fuad 2008). Outer model dievaluasi dengan menggunakan Convergent validity, Discriminant validity dan Composite reliability dan Inner model dievaluasi dengan menggunakan $\mathrm{R}^{2}$ dan uji $\dagger$ (Ghozali, 2006). Inner model dalam studi ini adalah sbb:

$$
\begin{array}{ll}
\eta_{1} & =\gamma_{11} \xi_{1}+\zeta_{1} \\
\eta_{2} & =\gamma_{21} \xi_{1}+\beta_{21} \eta_{1}+\zeta_{2} \\
\eta_{3} & =\gamma_{31} \xi_{1}+\beta_{31} \eta_{1}+\beta_{32} \eta_{2}+\zeta_{3}
\end{array}
$$

\section{HASIL DAN PEMBAHASAN}

\section{Hasil Uji Outer Model}

Tabel 1

Nilai Measurement Model (Loading)

\begin{tabular}{|c|l|c|r|}
\hline \multirow{3}{*}{ Konstruk } & \multicolumn{1}{|c|}{ Indikator } & $\begin{array}{c}\text { Perusahaan } \\
\text { Besar }\end{array}$ & $\begin{array}{c}\text { Perusahaan } \\
\text { Kecil }\end{array}$ \\
\hline \multirow{4}{*}{ GCG } & $X 1$ (kepemilikan manajerial) & 0.3224 & -0.4369 \\
\cline { 2 - 4 } & $X 2$ (komisaris independent) & -0.4919 & $\mathbf{0 . 5 7 4 4}$ \\
\cline { 2 - 4 } & $X 3$ (komite audit) & 0.0638 & -0.5956 \\
\cline { 2 - 4 } & $X 4$ (kepemilikan institusional) & $\mathbf{0 . 5 9 7 5}$ & $\mathbf{0 . 6 6 5 9}$ \\
\hline
\end{tabular}

Sumber: Data Sekunder, 2007 (diolah)

Berdasarkan tabel di atas indikator GCG pada perusahaan besar yaitu (X1), (X2) dan (X3) dikeluarkan dari model karena nilai loadingnya <0.5. sehingga GCG pada perusahaan besar hanya mempunyai 1 indikator yaitu X4. Sedangkan pada perusahaan kecil indikator GCG yang dikeluarkan dari model yaitu X1 dan X3, sehingga GCG pada perusahaan kecil mempunyai dua indikator yaitu X2 dan X4. Selanjutnya dilakukan re-estimasi pada model. Dari hasil re-estimasi, indikator-indikator GCG baik pada perusahaan besar maupun kecil memenuhi convergent validity, discriminant dan composite reliability. 


\section{Hasil Uji Inner Model}

\begin{tabular}{|c|c|c|c|c|c|}
\hline \multicolumn{6}{|c|}{$\begin{array}{c}\text { Tabel } 2 \\
\text { Hasil Uji Inner Model } \\
\end{array}$} \\
\hline \multicolumn{6}{|c|}{ Perusahaan Besar } \\
\hline $\begin{array}{c}\text { Hubungan } \\
\text { Variabel }\end{array}$ & $\begin{array}{c}\text { Entire Sample } \\
\text { Estimate }\end{array}$ & T-Statistic & T-Tabel & R-Square & Keterangan \\
\hline CSR -> AR & 0.550 & 3.729 & 2.045 & 0.256 & Signifikan \\
\hline GCG -> AR & -0.002 & -0.016 & 2.045 & 0.256 & Tidak Signifikan \\
\hline EVA $->$ AR & -0.115 & -0.816 & 2.045 & 0.256 & Tidak Signifikan \\
\hline CSR -> EVA & 0.539 & 3.533 & 2.045 & 0.320 & Signifikan \\
\hline GCG -> EVA & 0.317 & 1.645 & 2.045 & 0.320 & Tidak Signifikan \\
\hline GCG -> CSR & -0.209 & -1.182 & 2.045 & 0.043 & Tidak Signifikan \\
\hline \multicolumn{6}{|c|}{ Perusahaan Kecil } \\
\hline $\begin{array}{l}\text { Hubungan } \\
\text { Variabel }\end{array}$ & $\begin{array}{c}\text { Entire Sample } \\
\text { Estimate }\end{array}$ & T-Statistic & T-Tabel & R-Square & Keterangan \\
\hline CSR -> AR & -0.288 & -2.520 & -2.045 & 0.393 & Signifikan \\
\hline GCG ->AR & 0.278 & 1.835 & 2.045 & 0.393 & Tidak Signifikan \\
\hline EVA -> AR & 0.600 & 4.101 & 2.045 & 0.393 & Signifikan \\
\hline CSR -> EVA & 0.102 & 0.911 & 2.045 & 0.090 & Tidak Signifikan \\
\hline GCG -> EVA & -0.279 & 0.168 & 2.045 & 0.090 & Tidak Signifikan \\
\hline GCG -> CSR & -0.040 & 0.115 & 2.045 & 0.002 & Tidak Signifikan \\
\hline
\end{tabular}

Sumber: Data Sekunder, 2007 (diolah)

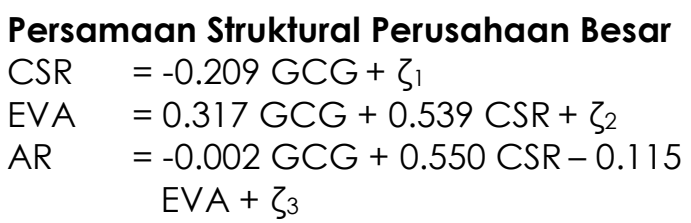

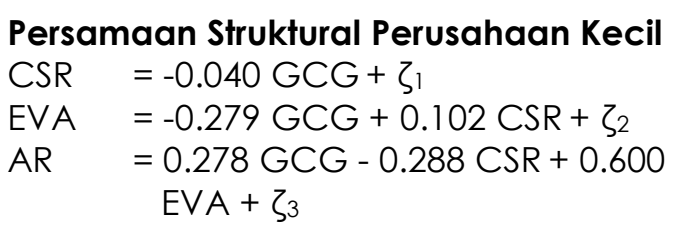

Dari Tabel di atas terlihat bahwa pada perusahaan besar CSR berpengaruh positif signifikan terhadap abnormal return. Pada perusahaan kecil CSR berpengaruh negatif signifikan terhadap abnormal return. Ada perbedaan uji hipotesis, maka hipotesis pertama $(\mathrm{H} 1)$ diterima. Perusahaan besar yang menerapkan CSR akan direspon positif oleh para pelakU pasar khususnya para investor (Sayekti 2007). Sedangkan pada perusahaan kecil, CSR membuat ada biaya tambahan yang dapat menempatkan perusahaan dalam keadaan ekonomi yang tidak menguntungkan dibandingkan perusahaan lain yang kurang bertanggung jawab secara sosial (Auperle dalam Monika 2008). Investor beranggapan bahwa kegiatan CSR membebani perusahaan kategori size kecil, Hal tersebut akan membawa respon negatif dengan turunnya harga saham.

Pada perusahaan besar GCG berpengaruh negatif tidak signifikan terhadap abnormal return. Pada perusahaan kecil GCG berpengaruh positif tidak signifikan terhadap abnormal return. Ada perbedaan uji hipotesis, sehingga hipotesis kedua $(\mathrm{H} 2)$ diterima. Pengaruh negatif pada perusahaan kategori size besar disebabkan oleh kepemilikan institusional sebagai alat ukur GCG. Investor lembaga ini pada umumnya terdiri dari holding companies yang saling berafiliasi (Sudarma dalam Sugeng 2010). Dalam arti walaupun mereka sangat dominan tetapi mereka tidak independen, sehingga kepemilikan institusional sebagai fungsi monitoring tidak dapat berjalan dengan baik. Oleh karena itu publik merespon negatif hal tersebut. Pada perusahaan kecil, GCG juga di ukur dengan prosentase komisaris independen. Komisaris independen merupakan pihak dewan komisaris yang tidak terafiliasi dengan perusahaan. Dengan adanya dewan komisaris independen tersebut fungsi monitoring dalam pengelolaan perusahaan dapat berjalan. Namun pengaruh GCG terhadap abnormal return, baik pada perusahaan besar maupun kecil dianggap tidak penting, karena tidak signifikan. 
Pada perusahaan besar EVA berpengaruh negatif tidak signifikan terhadap abnormal return. Pada perusahaan kecil EVA berpengaruh positif signifikan terhadap abnormal return. Ada perbedaan uji hipotesis, sehingga hipotesis ketiga $(\mathrm{H} 3)$ diterima. Pada perusahaan besar EVA berpengaruh negatif tidak signifikan terhadap return saham. Sartono (2001) menyatakan bahwa perusahaan dengan EVA negatif dapat saja memiliki kinerja pasar yang positif, jika investor memiliki harapan akan perubahan yang lebih baik pada perusahaan di masa depan. Namun pengaruh ini pada perusahaan besar dianggap tidak penting, karena hasilnya tidak signifikan. Sedangkan Triatmojo (2009) menyatakan bahwa EVA merupakan ukuran kinerja yang berkaitan langsung dengan kemakmuran pemegang saham. Jika EVA naik maka return yang akan diterima pemegang saham juga akan mengalami kenaikan. Hal ini terbukti dengan hasil penelitian pada perusahaan kategori size kecil.

Pada perusahaan besar CSR berpengaruh positif signifikan terhadap EVA. Pada perusahaan kecil CSR berpengaruh positif tidak signifikan terhadap EVA. Ada perbedaan uji hipotesis, sehingga hipotesis keempat $(\mathrm{H} 4)$ diterima. Semakin banyak kegiatan CSR yang dilakukan perusahaan besar dan diungkapkan dalam laporan tahunan maka secara signifikan akan meningkatkan kinerja keuangan. Menurut Solomon dkk dalam Monika (2008) CSR dapat meningkatkan loyalitas karyawan dan konsumen, hal tersebut dapat mendukung perusahaan dalam menghasilkan laba operasi. Sedangkan pengaruh positif tidak signifikan CSR terhadap kinerja keuangan pada perusahaan size kecil disebabkan oleh kuantitas pengungkapan CSR yang sangat rendah pada perusahaan size kecil. Rata-rata pengungkapan hanya sebesar 23.19\% pada tahun 2007.

Pada size besar GCG berpengaruh positif tidak signifikan terhadap EVA. Sedangkan pada size kecil GCG berpengaruh negatif tidak signifikan terhadap EVA. Ada perbedaan uji hipotesis, sehingga hipotesis kelima $(\mathrm{H} 5)$ diterima. Tanda positif pengaruh GCG terhadap kinerja keuangan pada perusahaan besar disebabkan kepemilikan institusi asing yang lebih besar dibandingkan dengan perusahaan kecil. Menurut Hapsoro (2007) Institusi asing lebih baik dalam melakukan monitoring dalam perusahaan, hal ini dapat mendorong terjadinya peningkatan kinerja keuangan perusahaan. Pada perusahaan size kecil mayoritas kepemilikan institusionalnya adalah institusi domestik. Gunarsih dalam Hasporo (2007) menyatakan bahwa di negara-negara yang sedang berkembang, kepemilikan institusi domestik dalam jumlah besar justru merepresentasikan kepentingan mereka sendiri dan mengorbankan kepentingan pemegang saham minoritas. Studi Gunarsih menunjukkan bahwa kepemilikan institusi domestik berpengaruh negatif terhadap kinerja perusahaan. Namun pengaruh GCG terhadap kinerja keuangan dianggap tidak penting, karena tidak signifikan.

Pada perusahaan besar maupun kecil GCG berpengaruh negatif tidak signifikan terhadap CSR. Tidak ada perbedaan uji hipotesis, sehingga hipotesis keenam (H6) ditolak. Hasil ini sejalan dengan Macmud (2008) yang menyatakan bahwa kepemilikan institusional di Indonesia belum mempertimbangkan tanggung jawab sosial sebagai salah satu kriteria dalam melakukan investasi, institusi ini cenderung tidak menekan perusahaan untuk melaksanakan kegiatan CSR dan mengungkapkannya dalam laporan tahunan perusahaan. Hasil ini juga tidak signifikan, sehingga pengaruh GCG terhadap CSR dianggap tidak penting. Nilai R-square dalam model persamaan struktural penelitian ini tergolong kecil yaitu kurang dari $40 \%$. Hal ini menunjukkan bahwa variabel terikat dalam penelitian ini lebih banyak dijelaskan oleh variabel lain diluar persamaan struktural.

\section{PENUTUP}

\section{Simpulan}

Return saham dan kinerja keuangan pada perusahaan besar dapat ditingkatkan melalui pelaksanaan dan pengungkapan kegiatan CSR pada laporan tahunan. Sedangkan untuk 
perusahaan kecil kegiatan CSR tidak dapat digunakan untuk meningkatkan return saham, karena kegiatan CSR tersebut dapat menurunkan return saham pada perusahaan dan CSR juga tidak berpengaruh terhadap kinerja keuangannya. Peningkatan return saham dan kinerja keuangan tidak dapat dilakukan melalui penerapan GCG yang hanya diukur dengan kepemilikan institusional dan komisaris independen. Peningkatan kinerja keuangan pada perusahaan kecil akan mengakibatkan peningkatan pada return saham perusahaan.

\section{Implikasi Teoritis dan Manajerial}

Implikasi teoritis dari temuan penelitian ini adalah pada perusahaan besar, CSR berpengaruh positif signifikan terhadap return saham dan kinerja keuangan. Pada perusahaan kecil CSR berpengaruh negatif signifikan terhadap return saham dan tidak berpengaruh terhadap kinerja keuangan. EVA pada perusahaan besar tidak berpengaruh terhadap return saham. Namun pada perusahaan kecil, EVA berpengaruh positif signifikan terhadap return saham. Implikasi Manajerial meliputi (1) Kegiatan CSR dapat meningkatkan return saham maupun kinerja keuangan pada perusahaan size besar. Sehingga CSR dapat digunakan sebagai strategi bisnis yang juga dapat meningkatkan kemakmuran para stakeholder; (2) Kegiatan CSR yang akan dilaksanakan oleh perusahaan size kecil, sebaiknya diukur berdasarkan kemampuan financial perusahaan. Karena kegiatan tersebut berindikasi membawa respon negatif dari para investor; (3) Kepemilikan institusional di Indonesia tidak dapat dijadikan sebagai monitoring kelola perusahaan. Karena kepemilikan institusional di Indonesia terdiri dari perusahaan-perusahaan holding company yang saling berafiliasi.

\section{Keterbatasan Penelitian dan Agenda Penelitian Mendatang}

Beberapa keterbatasan yang dialami peneliti, yang dapat dijadikan acuan untuk agenda penelitian mendatang adalah; (1) Jumlah sampel yg kecil. Untuk itu perlu penambahan sampel pada penelitian y.a.d; (2) Pengukuran GCG tidak dapat mencerminkan pelaksanaan GCG secara riil. Agenda penelitian y.a.d disarankan menggunakan ukuran yang dapat mecerminkan pelaksanaan GCG di Indonesia, misalnya dari rating yang dikeluarkan oleh lembaga survei. Serta perlu menambah periodisasi data; (3) Terjadi ketidakseimbangan dalam membandingkan hasil penelitian yaitu pada variabel GCG. Hal ini terjadi karena pengeluaran indikator yang tidak memenuhi convergent validity. Untuk penelitian yang akan datang, Indikator GCG masuk dalam indikator formatif, sehingga penilaian indikator dilihat dari nilai weight dan signifikansi dari masing-masing indikator.

\section{DAFTAR PUSTAKA}

Amalia, S. Fala Dwi Yana. 2007. "Pengaruh Konservatisme Terhadap Penilaian Ekuitas Perusahaan Dimoderasi oleh Good Corporate Governance" UNHAS, $26-28$ Juli, SNA $X$, Makasar.

Andriyani, Ade, dkk. 2008. "Pengungkapan Corporate Social Responsibility (CSR) pada Official Website Perusahaan Studi Kasus PT. Unilever Indonesia Tbk". KOMMIT, Auditorium Universitas Gunadarma, Depok, 20-21 Agustus, ISSN: 141 1-6286

Anik, Sri. 2006. Teori Portofolio \& Analisis Investasi, cetakan I, Unissula Press, Semarang, 2006

Bodroastuti, Tri. 2009. "Pengaruh Struktur Corporate Governance terhadap Financial Distress (Studi pada Perusahaan Manufaktur ynag terdfatar di PT. BEl Periode 2003-2007)". Universitas Diponegoro, Semarang.

Dahli, Lely, dkk. 2008. "Pengaruh Corporate Social Responsibility terhadap Kinerja Perusahaan (Studi Empiris Pada Perusahaan yang Tercatat di Bursa Efek Indonesia Pada Tahun 2005 dan 2006)". Universitas Tanjung Pura Pontianak, 23-24 Juli, vol 4, SNA 11 
Fauzi, dkk. 2007. "The Link Between Corporate Social Performance and Financial Performance: Evidence from Indonesian Companies". Issues in Social and Environment Accounting, vol. 1, no. 1 June, PP. 149-159

Ghozali, Imam. 2006, Structural Equation Modeling Metode Alternatif dengan Partial Least Square. BP UNDIP, Semarang.

Ghozali, Imam, dkk. 2008. Structural Equation Modeling: Teori, Konsep, dan Aplikasi dengan Program Lisrel 8.80. edisi dua, BP UNDIP, Semarang.

Hakim, Rahman. 2006. "Perbandingan Kinerja Keuangan Perusahaan dengan Metode EVA, ROA, dan Pengaruhnya Terhadap Return Saham Pada Perusahaan Yang Tergabung Dalam Indeks LQ 45 Di Bursa Efek Jakarta". Universitas Islam Indonesia, Yogyakarta.

Hapsoro, Dody. 2007. "Pengaruh Struktur Kepemilikan terhadap Transparasi: Studi Empiris di Pasar Modal Indonesia". Jurnal Akuntansi \& Manajemen, vol. 18, No.2, Agustus, ISSN: 0853-1269.

Hartono, Jogiyanto. 2008. Teori Portofolio dan Analisis Investasi, edisi kelima, BPFE, Yogyakarta.

Indriantoro, Nur, dkk. 2002. Metode Penelitian Bisnis Untuk Akuntansi dan Manajemen, edisi pertama, BPFE, Yogyakarta.

Isnanta. 2008. "Pengaruh Corporate Governance dan Struktur Kepemilikan terhadap terhadap Manajemen Laba dan Kinerja Kevangan". Universitas Isalam Indonesia, Yogyakarta.

Jalal, Sukadi. 2009. A+CSR Indonesia www.csrindonesia.com. disampaikan dalam pelatihan Pelaporan Keberlanjutan, Bogor , 18-19 November.

Lako, Andreas, dkk. 2008. "CSR Bukan Beban, Tetapi Investasi". Kronik UNIKA, edisi sebelas, 30 Juni.

Machmud, Novita, dkk. 2008. "Pengaruh Struktur Kepemilikan terhadap Luas Pengungkapan Tanggung Jawab Sosial (CSR Disclosure) pada Laporan Tahunan Perusahaan: Studi Empiris Pada Perusahaan Publik yang Tercatat di Bursa Efek Indonesia Tahun 2006", SNA 11 Universitas Tanjung Pura Pontianak.

Marberya, Ni Putu Ena, dkk. 2007. "Pengaruh Pemoderasi Pertumbuhan Laba Terhadap Hubungan antara Ukuran Perusahaan, Debt to Equity Ratio dengan Profitabilitas Pada Perusahaan Perbankan yang Terdaftar di Bursa Efek Jakarta". Universitas Udayana, Bali.

Monika, Elsa R, dkk. 2008. "Analisis Hubungan Value Based Management dengan Corporate Social Responsibility dalam Iklim Bisnis Indonesia (Studi Kasus Perusahaan SWA 100 2006)", SNA XI Universitas Tanjung Pura Pontianak.

Nurlela, Rika, dkk. 2008. "Pengaruh Corporate Social Responsibility terhadap Nilai Perusahaan Dengan Prosentase Kepemilikan Manajemen sebagai Variabel Moderating (Studi Empiris Pada Perusahaan yang Terdaftar di Bursa Efek Jakarta)". SNAXI Universitas Tanjung Pura Pontianak.

Pranata, Yudha. 2006. "Pengaruh Penerapan Corporate Governance Terhadap Kinerja Keuangan Perusahaan". Universitas Islam Indonesia, Yogyakarta.

Rahayu, Mariana Sri. 2007. "Analisis Pengaruh EVA dan MVA Terhadap Return Saham pada Perusahaan Manufaktur di Bursa Efek Indonesia". Universitas Islam Indonesia, Yogyakarta.

Sam'ani. 2008. "Pengaruh Good Corporate Governance dan Leverge Terhadap Kinerja Keuangan pada Perusahaan Perbankan yang Terdaftar di BEl Tahun 2004-2007". Universitas Diponegoro, Semarang. 
Sartono, Agus. 2001. Manajemen Keuagan Teori dan Aplikasi. edisi keempat, BPFE, Yogyakarta.

Sayekti, Yosefa, dkk. 2007. "Pengaruh CSR Disclosure Terhadap Earning Response Coefficient (Suatu Studi Empiris Pada Perusahaan yang Terdaftar di Bursa Efek Jakarta)", SNA X UNHAS, Makasar.

Solihin, Ismail. 2009. Corporate Social Responsibility From Charity to Sustainability. jilid I, Salemba Empat, Jakarta.

Sugeng, Bambang. 2009. "Pengaruh Struktur Kepemilikan dan Struktur Modal terhadap Kebijakan Inisiasi Dividen di Indonesia".Jurnal Ekonomi Bisnis, tahun 14, nomor 1, Maret, ISSN:0853-7283.

Suharto, Edi. 2008. "Menggagas Standar Audit Program CSR". CSR Audit, Bandung.

Taufik. 2007. "Pengaruh Pendekatan Traditional Accouting dan Economic Value Added Terhadap Stock Return Perusahaan Sektor Perbankan di PT. Bursa Efek Jakarta", Jurnal Manajemen dan Bisnis Sriwijaya, Vol. 5, No 10 Desember.

Triatmojo, Hari Murti. 2009. "Pengaruh Economic Value Added dan Profitabilitas Perusahaan Terhadap Return Pemegang Saham (Suatu Studi Empiris Pada Perusahaan Manufaktur yang Terdaftar di Bursa Efek Jakarta)". Universitas Muhamadiyah, Surakarta.

Tsoutsora, Margarita. 2004. "Corporate Social Responsibility and Financial Performance". Haas School of Business Berkeley, California.

Utami, Dian Irwanti Tias. 2009. "Pengaruh Kinerja Keuangan Terhadap Return Saham pada Perusahaan Basic Industry and Chemical yang Terdaftar di Bursa Efek Indonesia.

Wardani, Diah Kusuma. 2008. "Pengaruh Corporate Governance Terhadap Kinerja Keuangan Perusahaan Indonesia". Universitas Islam Indonesia, Yogyakarta.

Yuniasih, Ni Wayan, dkk. 2008. "Pengaruh Kinerja Keuangan Terhadap Nilai Perusahaan dengan Pengungkapan Corporate Social Responsibility dan Good Corporate Governance sebagai Variabel Moderating". Universitas Udayana. 